\title{
KEMANDIRIAN MASYARAKAT DESA SEKARPUTIH KECAMATAN TEGALAMPEL DALAM MENINGKATKAN KUALITAS TANAH MELALUI PEMBUATAN PUPUK ORGANIK KOTORAN SAPI
}

\author{
Basuki1), Sukron Romadhona'), Listya Purnamasari'1), Vega Kartika Sari') \\ 1)Program Studi IlmuTanah, Fakultas Pertanian, Universitas Jember, Jember, Jawa Timur, Indonesia \\ Corresponding author : Basuki \\ E-mail : basuki@unej.ac.id
}

Diterima 16 Oktober 2021, Direvisi 16 Desember 2021, Disetujui 16 Desember 2021

\begin{abstract}
ABSTRAK
Lahan pertanian mengalami penurunan kesuburan tanah dengan indikasi nilai C-Organik $<1 \%$ sangat luas, termasuk di Desa Sekarputih Kabupaten Bondowoso. Masyarakat Desa Sekarputih sebagian besar bermata pencaharian sebagai petani dan peternak. Survei awal menunjukkan bahwa kotoran sapi yang dihasilkan oleh ternak belum dimanfaatkan secara optimal. Banyak kotoran sapi yang dibiarkan begitu saja sehingga menimbulkan masalah lingkungan seperti bau yang menyengat. Tujuan dari program pengabdian ini adalah sosialisasi dan pelatihan pembuatan pupuk organik yang berasal dari kotoran sapi sebagai alternatif untuk meningkatkan bahan organik tanah dan mengurangi permasalahan lingkungan. hasil kegiatan pengabdian menunjukkan bahwa peserta sangat aktif dan antusias dalam bertanya dan menjawab pertanyaan dalam kegiatan sosialisasi, dan antusias aktif dalam praktek langsung pada tahap pelatihan.
\end{abstract}

Kata kunci: pelatihan; pupuk organic; kotoran sapi; ternak.

\begin{abstract}
Agricultural land experienced degradation of soil fertility with indicated C-Organic value $<1 \%$ very widely, including in Sekarputih Village, Bondowoso Regency. The people of Sekarputih village mostly make a living as farmers and ranchers. The initial survey shows that cow dung produced by livestock has not been utilized optimally. A lot of cow dung is left alone which causes environmental problems such as a strong odor. The purpose of this service program is socialization and training on the manufacture of organic fertilizer derived from cow dung as an alternative to increasing soil organic matter and reducing environmental problems. the results of the service activities showed that the participants were very active and enthusiastic about asking and answering questions in socialization activities, and enthusiastically active in direct practice at the training stage.
\end{abstract}

Keywords: training; organic fertilizer; cow manure; livestock.

\section{PENDAHULUAN}

Lahan pertanian di Indoensia dalam decade terakhir menunjukkan kualitas tanah yang rendah. Kualitas tanah ditunjukkan oleh nilai kandungan karbon organik kurang dari $1 \%$. Syarat tanah yang sehat minimal memiliki kualitas tanah dengan kandungan C-Organik 2 \% (Basuki \& Sari, 2020; Sukri et al., 2020) . Penurunan kualitas tanah di lahan pertanian disebabkan oleh penggunaan bahan organik sebagai pupuk sudah tidak diterapkan lagi (Ratriyanto et al., 2019; Setiawati et al., 2019). Alasan sebagian besar petani tidak memupuk lahan pertanian dengan pupuk organik karena aplikasi pupuk yang diberikan ke lahan pertanian kuantitasnya tinggi, membutuhkan waktu dan tenaga yang banyak, sumber bahan yang relatif sulit yang harus memiliki sumber ternak sendiri, pupuk anorganik yang mudah dan dosis yang rendah. Fenomena tersebut menyebabkan penurunan kualitas hasil pertanian, dan peningkatan serangan hama dan penyakit baru di lokasi setempat (Damanhuri et al., 2020; Sari et al., 2020). Peningkatan serangan hama penyakit, mengharuskan petani menggunakan bahan kimia untuk mengendalikan seperti insektisida, fungisida, bakterisida, dan bahan sejenis lainnya. Penggunaan bahan sintetik pengendali hama dan penyakit pengganggu menyebabkan membunuh organisme yang sebetulkanya bukan sasaran utama dari bahan tersebut. Kita bisa lihat kondisi tersebut dilahan sawah, tahun 90-an kita dapat menemukan ikan liar di saluran draenase, lahan sawah yang saat musim panen padi dengan cara pengeringan sawah sekaligus panen ikan yang ada di lahan swah, ular sawah yang sudah tidak kita temukan di lahan sawah 
sebagai pengendali tikus, jamur metharizium pengendali serangga sudah tidak ada, dan organisme menguntungkan lain sudah menurun. Akibat organisme pengendali hilang menyebabkan meledaknya hama dan penyakit seperti tikus, wereng, penyakit busuk batang, pengerek pucuk.

Menurut (Apriscia C.Y., Nurul Barunawati, 2016; Basuki et al., 2015), penggunaan pupuk organik baik secara individu maupun dengan kombinasi dengan pupuk anorganik mampu meningkatkan organisme pengendali hama dan penyakit seperti salah satunya jamur metharizium, ular yang menjadi pengendali tikus tidak mati sehingga mampu mengendalikan hama tikus. Kabupaten Bondowoso merupakan kabupaten yang menjadi pelopor dalam pertanian organik yang berada di Desa Lombok Kulon, tetapi belum merata ke desa-desa lain. Desa Sekarputih merupakan desa yang berada di Kecamatan Tegalampel Kabupaten Bondowoso yang memiliki luas lahan sawah 547 ha yang terbagi atas 212 ha sawah irigasi teknis, dan 335 sawah tadah hujan. Hasil identifikasi awal kandungan bahan organik di beberapa titik pengamatan baik sawah irigasi teknis dan sawah tadah hujan menunjukkan nilai kandungan C-Organik 0,9\% sehingga pupuk organik sangat perlu diaplikasikan. Bahan baku pupuk organik di Desa Sekarputih tergolong melimpah dan banyak limbah pertanian yang terlantarkan tidak termafaatkan. Limbah pertanian yang tidak termanfaatkan tersebut diakibatkan oleh pemiliki ternak yang sekaligus pemilik sawah tidak mengetahui cara mengolah kotoran sapi menjadi pupuk organik atau kompos. Ketidaktahuan tersebut dibuktikan dengan banyak kotoran sapi yang dibuang ke sungai atau dibakar untuk perapian penghangat serta pengusir serangga di kandang sapi.

\section{METODE}

\section{Tempat dan Waktu Pelaksanaan}

Program pengabdian masyarakat dengan judul "Kemandirian Masyarakat Desa Sekarputih Kecamatan Tegalampel Dalam Meningkatkan Kualitas Tanah Melalui Pembuatan Pupuk Organik Kotoran Sapi" dilaksanakan di Kelompok Tani Sekarjaya II Desa Sekarputih Kecamatan Tegalampel Kabupaten Bondowoso. Adapun titik Koordinat Desa Sekarputih 113.82 BT, -7.89 LS. Pelasanaan kegiatan dilakukan pada bulan Agustus-September Tahun 2021.

\section{Sasaran Kegiatan \\ Sasaran kegiatan pengabdian masyarakat di Desa Sekarputih yaitu kelompok}

tani sekarjaya II. Kelompok tani sekarjaya II memiliki anggota \pm 50 anggota.

\section{Metode dan Pendekatan Pelaksanaan}

Kegiatan pengabdian masyarakat dilaksanakan dengan metode sosialisasi dan pelatihan. Sosialisasi melalui pemaparan materi terkait dengan pengetahuan dan memberi wawasan awal dengan topik pengabdian. Pelatian melalui peran aktif peserta dalam membuat bahan atau mengaplikasikan sesuatu dengan dipandu melalui langkah-langkah tutorial(Basuki et al., 2021). Berdasarkan metode yang digunakan dituangkan dalam beberapa kegiatan diantaranya:

\section{Persiapan}

Persiapan dilakukan sebelum kegiatan sosialisasi dan pelatihan dimulai. Persiapan yang dikerjakan meliputi pemilihan lokasi, pemilihan mitra, peninjauan awal untuk mendapatkan permasalahan yang harus diselesaikan bersama, menentukan jadwal kegiatan, persiapan alat dan bahan yang akan di gunakan dalam kegiatan pengabdian.

2. Sosialisasi

Sosialisasi dilaksanakan melalui penyuluhan dengan memaparkan materi terkait peran bahan organik, kandungan nutrisi dalam bahan organik, aplikasi dan penentuan dosis bahan organik, pemaparan video pembuatan pupuk organik.

\section{Pelatihan}

Pelatihan dilakukan dengan mengedepankan peran aktif peserta dalam membuat produk pupuk organik dengan bahan baku kotoran sapi. Peserta diminta untuk mempraktekkan melalui bahan dan alat yang sudah disediakan.

\section{Pendampingan}

Pendampingan dilakukan melalui kegiatan konsultasi baik langsung datang ke mitra maupun melalui media komunikasi seperti telepon,whatsapp, telegram atau media lain yang mendukung proses pendampingan.

\section{Evaluasi}

Evaluasi kegiatan dilakukan melalui wawancara beberapa responden terkait pengetahuan pembuatan pupuk organik dengan bahan baku kotoran sapi, cara mendapatkan bahan dan alat yang digunakan untuk pembuatan pupuk organik, dan keberlakutan program setelah selesai kegiatan.

\section{HASIL DAN PEMBAHASAN Manfaat Bahan Organik}

Kotoran sapi di Desa Sekarputih dapat kita temukan dengan kuantitas yang tinggi. Tiap keluarga atau rumah penduduk di desa ini memiliki ternak minimal 2 ekor sapi. Tiap sapi menghasilkan 25 Kilogram kotoran padat tiap 
hari. Kotoran padat tersebut di tampung di sekitar kandang yang menimbukan polusi air saat hujan, dan bau yang nyengat bisa mencapai radius 20 Meter. Bau yang menyengat disebabkan oleh proses dekomposisi kotoran sapi secara anaerob. Penumpukan kotoran yang terus-menerus tiap hari menyebabkan kotoran tidak bisa terdekomposisi secara sempurna. Melalui program pengabdian masyarakat dengan pembuatan pupuk organik dari kotoran sapi terdapat beberapa manfaat diantaranya:

1. Mengurangi limbah peternakan dan polusi yang berada di lingkungan penduduk.

2. Meningkatkan pendapatan masyarakat dengan menjual hasil akhir pembuatan pupuk organik dari kotoran sapi.

3. Meningkatkan kualitas tanah pertanian dengan peningkatan bahan organik tanah.

4. Menjadi solusi saat kelangkaan pupuk anorganik di pasaran

5. Meningkatkan produksi pertanian yang dibudidayakan(Safitri Adnan et al., 2015; Sari et al., 2021; Soraya Santi, 2008; Sukri et al., 2020).

Menurut (Basuki, 2020), tanah di wilayah sekar putih merupakan tanah dengan ordo Inceptisol yang merupakan tanah dengan tingkat kesuburan tanah yang rendah. Kesuburan tanah yang rendah di lihat dari kandungan bahan organik tanah dibawah $1 \%$, sehingga perlu penambahan bahan organik tanah dari luar dalam bentuk pupuk organik yang mampu memberikan kondisi tanah yang sehat dan berkualitas. Sistem pertanian di Desa Sekar putih termasuk dalam sistem pertanian tadah hujan, yaitu pemanfaatan lahan dengan menggantungkan air dari hujan sehingga pada musim kemarau lahan tidak dimanfaatkan (bero). Manfaat bahan organik pada lahan pertanian diantara:

1. Pemanfaatan kondisi bero dengan aplikasi bahan organik mampu meningkatkan unsur hara dalam tanah,

2. Menyediakan makanan bagi organisme yang menguntungkan seperti Azotobacter, Speudomonas, bakteri pelarut pospat, bakteri pelarut nitrogen, bakteri pelarut kalium dalam memnyediakan unsur hara dari tidak tersedia menjadi tersedia.

3. Meningkatkan kemampuan tanah dalama mengikat air sehingga air tanah dapat bertahan lebih lama,

4. Mebuat tanah menjadi gembur dan mudah diolah,

5. Menyediakan unsur hara baik makro maupun mikro bagi tanaman.

\section{Sosialisasi Pemanfaatan Bahan Organik} Tanah

Kegiatan sosialisasi dilaksanakan pada awal Bulan September 2021. Sosialisasi terkait pemanfaatan bahan organik tanah di Desa Sekarputih Kecamatan Tegalampel Kabupaten Bondowoso dihadiri oleh anggota kelompok tani Sekarjaya II, mahasiswa Program Studi IImu Tanah, Dosen, masyarakat yang berminat terkait pertanian organik. Total peserta yang hadir dalam sosialisasi berjumlah 12 peserta. Peserta sangat antusias dalam mengikuti kegiatan sosialisasi, beberapa peserta sosialisasi sangat tertarik karena dengan adanya kegiatan ini mampu memberi wawasan terhadap mereka dalam mengatasi kelangkaan pupuk, dan mengatasi polusi udara disekitar rumah yang disebabkan oleh kotoran sapi yang banyak. Menurut (Basuki et al., 2021; Sari et al., 2021), peserta merupakan asset utama dalam kegiatan sosialisasi, interaksi antara narasumber-peserta yang aktif dalam suatu acara merupakan Langkah awal dalam keberhasilan kegiatan.

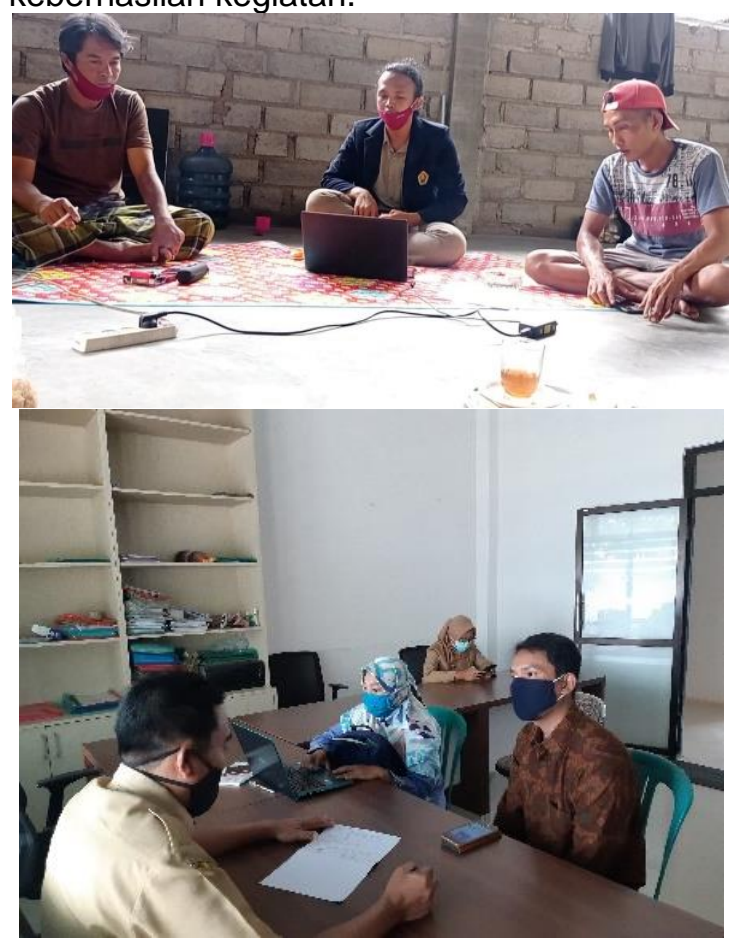

Gambar 1. Sosialisasi Kegiatan

(Sumber : Dokumentasi Pribadi).

Kegiatan sosialisasi memaparkan manfaat bahan organik bagi tanaman budidaya, cara identifikasi kadar bahan organik tanah yang rendah melalui kondisi panjang akar tanaman gulma, penentuan dosis dan cara aplikasi pupuk organik yang tepat dilahan pertanian. 


\section{Pelatihan Pembuatan Pupuk Organik dari Kotoran Sapi}

Kegiatan pelatihan dilaksanakan pada minggu ke 2 pada Bulan September 2021. Pelatihan dilaksanakan di kandang anggota kelompok tani sekar jaya II. Kegiatan pelatihan dihadiri oleh 7 orang yang terdiri atas anggota kelompok tani sekar jaya II, dan mahasiswa program studi ilmu tanah. Metode yang digunakan dalam kegiatan pelatihan yaitu ceramah dan praktek langsung yang menitikberatkan peran aktif peserta pelatihan. Adapun tahapan dalam pembuatan pupuk organik yang berasal dari kotoran sapi sebagai berikut:

1. Menyiapkan alat dan bahan seperti cangkul, sekop, biodekomposer, ember, gembor, pengaduk, air, terpal, alat pengukur suhu, saringan, gelas ukur, kapur dolomit, molase.

2. Menyiapkan kotoran sapi sebanyak 1ton sebagai bahan yang akan didekomposisikan.

3. Menyiapkan larutan decomposer dalam ember dengan komposisi 1 liter biodekomposer, $1 \mathrm{~kg}$ molase, 20 liter air.

4. Mengaduk larutan biodekomposer agar merata.

5. Memasukkan larutan biodekomposer dalam gembor untuk memudahkan aplikasi.

6. Memgambil kotoran sapi $2 \mathrm{kw}$ dan meratakan selanjutnya disiram dengan biodekomposer secara merata.

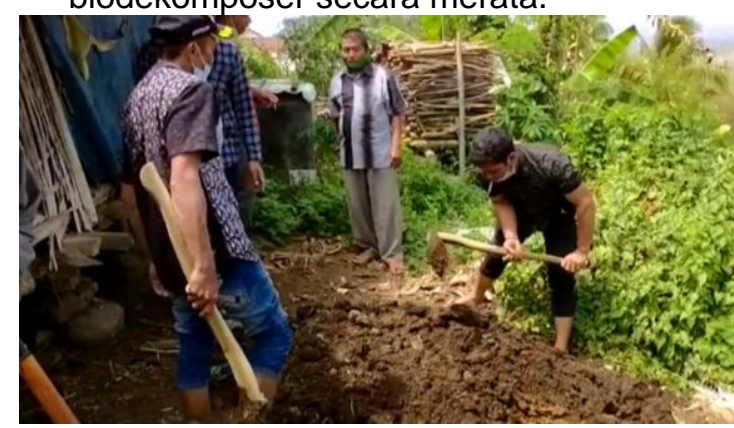

Gambar 2. Pelatihan Pembuatan Pupuk Organik dari Kotoran Sapi

(Sumber : Dokumentasi Pribadi).

7. Mengabil kotoran sapi sebanyak $2 \mathrm{KW}$, tumpuk diatas kotoran sapi yang sudah diberi biodekomposer sebelumnya dan ratakan, selanjutnya diberi biodekomposer dengan gembor diatasnya secara merata.

8. Kegiatan pada nomor 7., dilakukan secara berulang sampai bahan dan biodekomposer habis.

9. Menutup kotoran sapi yang diberi biodekomposer dengan terpal untuk menghindari air hujan.

10.Mengamati kematangan biodekomposer tiap 7 hari sekali dengan menggunakan cek suhu. Kompos yang sudah matang ditandai dengan nilai suhu sama tidah jauh berbeda dengan suhu lingkungan sekitar.

\section{Monitoring dan Evaluasi}

Kegiatan monitoring dan evaluasi dilaksanakan pada minggu ketiga dan keempat bulan September 2021. Kegiatan monitoring dan evaluasi terutama spengecekan suhu secara bersama-sama proses pengomposan pupuk organik yang berasal dari kotoran sapi dan evaluasi tindak lanjut terkait keberlanjutan pembuatan pupuk organik. Hasil pengecekan suhu pada 7 hari setelah aplikasi dengan termometer menunjukkan nilai suhu didalam kompos $51^{\circ} \mathrm{C}$, sedangkan suhu lingkungan 30 $31^{\circ} \mathrm{C}$. Pengecekan suhu pada 14 hari setelah aplikasi pembuatan kompos menunjukkan nilai suhu didalam kompos $59^{\circ} \mathrm{C}$, sedangkan suhu lingkungan $29-31^{\circ} \mathrm{C}$. Suhu dalam kompos pada hari ke 7, dan meningkat pada hari ke 14 menunjukkan biodekomposer yang diberikan kedalam kotoran sapi sebagai agen perombak berjalan secara aktif. Hasil evaluasi melalui tanya jawab dengan peserta pelatihan bahwa peserta sangat senang terhadap pelatihan pembuatan pupuk organik dari kotoran sapi, dan kegiatan ini akan dilanjutkan ditiap-tiap peserta yang mempunyai ternak sapi sebagai pupuk organik yang mendampingi pupuk anorganik dilahan sawah.

\section{SIMPULAN DAN SARAN}

Kegiatan pengabdian kemiteraan di Kelompok Tani Sekar Jaya II di Desa Sekarputih Kecamatan Tegalampel Kabupaten Bondowoso dengan tema pembuatan pupuk organik dengan bahan baku kotoran sapi melalui beberapa kegiatan sosialisasi dan pelatihan berjalan lancar. Peran aktif peserta dalam kegiatan pengabdian kemiteraan ini ditunjukkan dengan antusias tanya jawab, dan antusias dalam praktek langsung pada tahap pelatihan.

Harapannya pembuatan pupuk organik di kelompok tani Sekarjaya II dapat terintegrasi terpusat dan monitoring kegiatan dapat dilaksanakan secara terus-menerus dan berkesinambungan.

\section{UCAPAN TERIMAKASIH}

Penulis mengucapkan banyak terima kasih kepada Universitas Jember yang telah memberi dukungandalam kelancaran program pengabdian kemiteraan melalui dana stimulus melalui hibah Program Pengabdian kemiteraan Tahun 2021.

\section{DAFTAR RUJUKAN}

Apriscia C.Y., Nurul Barunawati, dan K. P. . (2016). Pengaruh Jenis Dan Takaran 
Pupuk Organik Terhadap Pertumbuhan Bibit Tanaman Tebu (Saccharum Officinarum L.) Di Polybag. Plantropica Journal of Agricultural Science, 1(2), 9-15.

Basuki, B. (2020). Pemetaan Tipologi Dan Kesesuaian Varietas Tanaman Tebu Berdasarkan Karakteristik Lahan Dan Tanah Di Jatiroto Lumajang. Buletin Tanaman Tembakau, Serat \& Minyak Industri, 12(1), 34. https://doi.org/10.21082/btsm.v12n1.2020 $.34-44$

Basuki, B., \& Sari, V. K. (2020). Efektifitas Dolomit Dalam Mempertahankan $\mathrm{pH}$ Tanah Inceptisol Perkebunan Tebu Blimbing Djatiroto. Buletin Tanaman Tembakau, Serat \& Minyak Industri, 11(2), 58.

https://doi.org/10.21082/btsm.v11n2.2019 $.58-64$

Basuki, Novikarumsari, N. D., Ibanah, I., \& Fariroh, I. (2021). Pemberdayaan Masyarakat Desa Sukamakmur Kabupaten Jember dalam Budidaya Lobster Air Tawar.

Basuki, Purwanto, B. H., Sunarminto, B. H., Nuryani, S., Utami, H., Tanah, I., Pertanian, F., \& Yogyakarta, U. G. M. (2015). Analisis Cluster Sebaran Hara Makro dan Rekomendasi Pemupukan untuk Tanaman Tebu (Saccharum officinarum Linn .) Cluster Analysis of Macro Nutrient Distribution and Fertilization Recommendations for Sugarcane ( Saccharum officinarum Linn .). 18(3), 118-126.

Damanhuri, Erdiansyah, I., Eliyatiningsih, Pratama, A. W., \& Sari, V. K. (2020). Pelatihan Enkapsulasi Pupuk Rhizobium spp pada Media Cair dan Granular untuk Tanaman Kedelai di Desa Sukorejo Kecamatan Bangsalsari Kabupaten Jember. Journal of Innovation and Applied Technology, 6(2), 1025-1030.

Ratriyanto, A., Widyawati, S. D., P.S. Suprayogi, W., Prastowo, S., \& Widyas, N. (2019). Pembuatan Pupuk Organik dari Kotoran Ternak untuk Meningkatkan Produksi Pertanian. SEMAR (Jurnal IImu Pengetahuan, Teknologi, Dan Seni Bagi Masyarakat), 8(1), 9-13. https://doi.org/10.20961/semar.v8i1.4020 4

Safitri Adnan, I., Utoyo, B., Any Kusumastuti, dan, Jurusan Budidaya Tanaman Perkebunan dan, M., \& Pengajar Jurusan Budidaya, S. (2015). Pengaruh Pupuk NPK dan Pupuk Organik terhadap Pertumbuhan Bibit Kelapa Sawit (Elaeis guineensis Jacq.) di Main Nursery (The
Effect of NPK Fertilizer and Organic Fertilizer on the Growth of Oil Palm [Elaeis guineensis Jacq.] Seedling in Main Nursery). Jurnal AIP, 3(2), 69-81.

Sari, V. K., Basuki, Mandala, M., Novikarumsari, N. D., \& Erdiansyah, I. (2021). Pemberdayaan Masyarakat Desa Slateng Kecamatan Ledokombo Jember Mengolah Limbah Serbuk Gergaji Sengon Menjadi Biochar. 2-6.

Sari, V. K., Ma'rufah, S., \& Rusdiana, R. Y. (2020). Pemanfaatan Vinasse sebagai Pupuk Organik Cair untuk Meningkatkan Pertumbuhan dan Hasil Bunga Kol (Brassica oleracea var. Botrytis L.). Jurnal Penelitian Pertanian Terapan, 20(1), 18. https://doi.org/10.25181/jppt.v20i1.1552

Setiawati, T. C., Basuki, \& Sulistyawati, N. (2019). Pengamatan Kesuburan Tanah, Pemanfaatan Organisme Tanah Untuk Pengendali Hama Uret Serta Perbaikan Manajemen Laboratorium Berbasis ISO 17025. Jurnal Pengabdian Masyarakat IPTEKS, 5(2), 176-181.

Soraya Santi, S. (2008). Kajian Pemanfaatan Limbah Nilam Untuk Pupuk Cair Organik. Jurnal Teknik Kimia, 2(2), 170-175.

Sukri, M. Z., Firgiyanto, R., Sari, V. K., \& Basuki, B. (2020). Kombinasi Pupuk Kandang Sapi, Asam Humat Dan Mikoriza Terhadap Infeksi Akar Bermikoriza Tanaman Cabai Dan Ketersediaan Unsur Hara Tanah Udipsamments. Jurnal Penelitian Pertanian Terapan, 19(2), 142. https://doi.org/10.25181/jppt.v19i2.1450 